\title{
FUTURE DIRECTIONS FOR THE STUDY OF VALUES AND EDUCATIONAL LEADERSHIP
}

\section{Gholamreza Shams*}

Reflective in their practice systems of values may vary from one individual to another. Multiple meanings and variations in interpretations have significant implications for schooling in general and educational leaders in particular. Clarifying the differences in interpretations of means and end values is a real challenge for educational leaders. It is incumbent on moral leaders to facilitate the understanding of and differentiation between educational values that are desirable and those that are motivated by self-interests. The developing trends to democratise and decentralise educational decision-making embody a holistic approach to leadership. Contextual ambiguity enveloping educational leaders engaged in the practice of moral leadership. There are some aspects, which have definite implications for future directions in the study of values and educational leadership.

Two decades ago, Scott and Hart (1979) sharply criticised those traditional bureaucratic organisations where management tends to be "heavily weighted toward the expedient by people who have been trained to consider value questions as impractical, even foolish" (p. 40). In the field of educational administration, Thomas Greenfield (1979) warned, "we should begin to regard with healthy scepticism the claim that a general science of organization and administration is at hand"

* Research Scholar in Education, Dept. of Education, Regional Institute of Education (NCERT), Manasagangotri, Mysore 570006, India. Email: g_shams_m@yahoo.com Mobile: $(+91) 9845194515$ 
(p. 12). Similarly, Christopher Hodgkinson (1978) said that leadership is a function of self-knowledge and values. He amplified the shortcomings of a science of administration, reminding that "science itself stops short at the edge of voluntarism, at the frontiers of conscious choice". He distinguishes between administration and management: " ... the former opening upon the limitless horizons of philosophy, the latter upon the restricted field of vision right and proper to science and technology". Accordingly, he critiques two deep-seated, grand assumptions embedded in administrative theory: we are all honorable, and authority and leadership legitimize power. These "presumptive fallacies" serve to "divorce the administrator from problems of ethics, morals, values ... leaving in their place only problems of technique, of managerial efficacy and efficiency". Hodgkinson underscores the connection among the concepts of will, power and administration, arguing that administration is politics. Hence, leadership involves understanding the full spectrum of values from the self $\left(V_{1}\right)$ through to the cultural $\left(V_{5}\right)$, in order to perceive and ameliorate value conflicts. This process is necessarily both conscious and non-reactive and, therefore, demands that the leader have a knowledge of self. To facilitate self-revelation, Hodgkinson calls for an "education of the will". In this way, he asserts, leadership involves an appreciation of the entire range of values through "an independent $\mathrm{V}$, interpretation" - which may ultimately result in "a triumph of the will" (Holdgkinson, 1978, pp. 6-21).

As Telford (1996) suggests, reconceptualizing leadership to include values, politics, power and the leader's triumphant will alerts us to its "moral connection". It is this moral connection which is reflected in much of the recent discussion, debate and research in educational administration literature. For instance, in relation to the works contained herein Begley declares: "The debate has not able, it has intensified!" That moral dimension of educational leadership is particularly significant in this postmodern epoch: "given the character of the times... educators and those interested in education will increasingly be making moral judgements in a world where traditional ethical guidelines are often are little assistance in the matters at hand" (Ryan, 2000, p. 120).

A continuing quest to better understand the nature and function of values and the manner and situations in which educational leaders attempt to resolve value conflicts characterises many of the ideas presented, analysed and evaluated by authors who their ideas have used in this paper. Some of the overarching themes which have emerged are those concerning:

- Determining "altruistic attitudes, values and beliefs" (Starratt), and a "morally explicit image of our preferred future" amidst "global and national turbulence" (Carlin and Goode); 
- Considering "the criteria and processes of value inquiry" (Beck);

- Acknowledging and understanding the contextuality of moral leadership (Ribbins, Evers, Lakomski);

- Recognising and critiquing the power relationships embedded in language use (Ryan);

- Clarifying, examining and addressing the relevancy gap between academic and practitioner perspectives on values (Begley);

- Viewing the perception, construction and use of time as a lens for examining what we value (Lafleur);

- Understanding the paradox of leadership couples (Gronn);

- Analysing the barriers to collaborative leadership (Leonard).

All of these themes re-affirm the importance of responding to the connection between leadership and its moral dimension.

This concern for and interest in the moral dimension of leadership should not be construed as an affront on the current moral state of educational leaders. Deliberations about moral leadership do not imply that today's educational leaders are uncaring or moral. "Indeed, it can be argued that in the case of educational administrators and other educators, good intentions are not the problem. Most of those who chose careers in schools appear to be rather altruistic and committed to an array of good outcomes for students" (Willower, 1994, p. 469). Nevertheless, Willower does shed tight on the difficulty for leaders. The real problem is negotiating the maze that separates good intentions from desired results" (p. 459). Furthermore, given the complex nature of values, the variations in value orientations embedded in competing educational ideologies, and the multiple choices which confront educational leaders in their daily school activities, "uncertainly rather than sureness" (Ryan, 2000, p. 1) is often the prevailing norm. Continued discourse among academics, researchers and practitioners are warranted. Future discourse on values, however, requires more clarity, coherence and relevance to administrative practice if closing the relevancy gap is to be a realised goal (Begley, 1996, p. 403).

A challenge to achieving value clarity, coherence and relevance is related to the dichotomous nature inherent in attempts to define the concept. Garforth (1985, p. 55) suggests that the word "value" is frequently used to signify worth. If something has worth then it is choiceworthy. For example, objects such as cloths, vehicles, and money may be considered to hold value. However, values such as happiness 
and contentment, considered to be affective (Rokeach, 1973, p. 6) in that they imply a state of mind (Garfith, 1985, p. 55) and values such as courtesy and kindness considered to have a "behavioral component" (Garforth, 1985; Rokeach, 1973) in that they refer to conduct, are not objects holding value but abstract notions of value. What follows is a bifurcated understanding of the concept of value: a person may value; or, an object or abstraction may hold value. In the former, values connote subjectiveness in that the worth of the value (e.g. money, happiness, kindness) is perceived or held by the individual. With regard to the latter, value is used in the objective sense in that may be used to indicate the thing that is being valued (e.g. money, happiness, kindness). In other words, value can refer to the values that a person subjectively perceives or holds, or it can refer to the object or abstraction that is being valued. This may not be a problem when discussing concrete notions such as money, cars or clothes; however, when considering abstractions like peace, truth or respect, the distinction between subjectiveness and objectiveness is an important one. Beck explains the distinction this way:

The term "values" has two connected but different meanings. In one sense, values are the things we pursue and consider important in life, the things we value. However, in the context of educational philosophy and theory the focus is normally on a narrower category, namely, the things that are worthy of valuing, the things those are actually valuable. This is what we are talking about when we say schooling should have a basis in values or students should be taught values: we do not mean just any value but rather a set of sound values (1996, p. 2, original emphasis).

When undertaking value research or engaging in discussing of educational values, it is important to be aware of variations in value positions; it is also important to understand the problems inherent in polarising these differences.

\section{Contextual Considerations}

Concomitant with the rejection of a general science of organization that embraced views such as Tylor's principles of scientific management and Fayol's general principles (Shafritz and OH, 1996) is the acknowledgement of the importance of context in administration and decision making. Again this raises the issue of moral leadership. For example, Evers puts forth the query: "How is ethical leadership in educational contexts possible?" In addressing his own question he reminds the futility of searching for universal moral rules. Lakomski (1987, pp. 70-82) supports this view stating, "Generality, insofar as it can be obtained, would be a matter of the coherence of accounts in a specified context". Everts goes on to claim that moral leadership and ethical knowledge are gained in the same manner as practical knowledge, "through learning from experience in complex, shiffing, context bound 
circumstances". Similarly, in outlining a "three-level approach to the study of leaders, leading, and leadership", Ribbins also assents the importance of context. His call for more research into the praxis of both the leaders and the led within a variety of contexts underscores the necessity of grounding theory in action and provides us with another direction in our plan for future contributions in the area of values and leadership. The ultimate goal, however, is not to develop a prescription of values, for, "the processes of valuation in school leadership situations are much too context bound to permit this quick fix ". Instead, a reasonable goal is to help future leaders become reflective in their practice - in another words, to develop values, sophistication and self-knowledge (Hodgkinson, 1991).

\section{Multiple Realities and Common Ground}

In addition to recognising the impact of context is the need to realize that systems of values (Rokeach, 1973, 1979) may vary from one individual to another. It is the different ordering of these value systems which accounts for "the richness and variety of individual differences in behaviour, attitudes, ideologies, self-preservations, judgement, evaluations, and rationalisations" (Rokeach, 1979, p. 49). Therefore, given the multitudes of different ways a relatively small number of values can be ordered, it is little wonder that value conflict is the "normal human condition" (Hodkinson, 1991, p. 102). It is also apparent that clarifying differences in value positions involves an attempt to navigate the many subtle complexities, the network of nuances and the gradations of differences associated with the varied positions. Multiple meanings and variations in interpretations have significant implications for schooling in general and educational leaders in particular. For example, when educators and other stakeholders debate and discuss educational values related to such issues as multicultural education, character education, caring schools, zero-tolerance policy, technology education, peace studies, cooperative learning, this question arises: Do participants in the discussion perceive these concepts as means values or end values? Put another way, is the educational value considered to be the end-purpose to schooling, or is it a means to achieve the end-purpose? For example, should character education be an overarching educational purpose? Beck (1993, p. 3) suggests that "being moral should be seen not as an end in itself but rather as a means (original emphasis) to the good life, for ourselves and others". He states that a "similar error has been made in education". The question is then, should character education be an end and of itself, or is it a means to an end. The answer is an important one because it can help clarify educational purposes and curriculum orientations.

Undoubtedly, clarifying the differences in interpretations of means and end values is a real challenge for educational leaders. This is commonly recognised to be 
due, at least partly, to the fact that we live in an increasingly pluralistic society comprised of different religions, ethnicities and social groups. The result is that there are potentially - and indeed probably - disparate value orientations among educational stakeholders. Educational leaders need to be fully aware of this disparity. However, Bossetti and Brown (1999, p. 232) point out that the challenge is made more complex because of "the ubiquity of change and uncertainty that pervades the post-modern era". The question arises regarding whether or not there are any absolutes in educational settings today. If there are, then next to be asked is whose absolutes are they? How, and by whom, can these absolutes be decided upon? Carlin and Goode (1999, p. 187) propose that schools and families "play a vital role in enculturing tomorrow's citizens and leaders into the values and meanings that constitute our essential humanity". They also emphasize the importance of moral leadership for the fulfilment of this role. The implication is that there may be some educational values that everyone can agree upon as basic. These would be common conceptualisations of what is desirable, rather than a promotion of particular group interests and desires. A corollary following from this position is that it is incumbent on moral leaders to facilitate the understanding of and differentiation between educational values that are desirable and those that are motivated by selfinterests.

\section{Holistic Leadership}

Perhaps an equally important missive to consider is that leadership does not necessarily reside in one individual. In fact, the developing trends to democratise and decentralise educational decision making embodies a holistic approach to leadership - "the idea of expanding opportunities for teachers, parents, and other local groups to play a role in guiding their school" (Duke and Canady, 1991, p. 130). More succinctly put, there is no limit to who can be a leader (Telford, 1996). Beck (1996) supports this notion and states that, "having been appointed as administrators does not mean that they must be - or must seem to be - wiser in value matters than others". Traditional forms of leadership, where the administrator is seen as the omnipotent arbiter of values, no longer work well in pluralistic societies. Leadership in a holistic sense involves "engaging people in the recreation of their work and their work environment, and indeed in the more intentional work of the continuous creation of themselves as individuals and as a community". This important process would necessarily mean valuing the "wide variety of languages that show up in schools" (Ryan, 2000, p. 7). While Ryan discusses the significance of respecting language diversity primarily in relation to students and curriculum, his message also has implications for collaboration and shared decision making. He reminds that not all language is equally valued and "power relationships have favoured it [standard English] over other languages". Given the importance of 
language as a "vehicle for voice", attention should be given to promoting respect for diverse forms of language and dialect in the interest of equalizing power in the values negotiation process.

Moral leadership, then, necessarily involves the democratic process of collaboration, and negotiation among participants in educational community. But there is more. Leadership involves "an artistic, imaginative dimension" and then proceed to present a model "through which the imagination is engaged in moral reasoning". Important "poietic" resources for educational leaders engaged in moral discourse are perspective, metaphor, narrative, the fine arts and irony, all of which leaders can creatively employ in their facilitation of moral decision-making processes. For them, the ultimate goal is that educational leaders be guided by a "practical wisdom, which incorporates both reason and imagination in a creative praxis".

Lafleur (1999, pp.170-185) also has something to say about imagination in his study on the effects of time. He posits that "organisational time is characteristically monochromic, future-oriented, compartmentalised and calendar based". In relation to the effects of time on aspects of schooling, Lafleur proposes a challenge to revisit and re-evaluate both the purpose and organisational structure of schools. In his words, "stretching our understanding of time can create possibilities and enable educators to make leaps of imagination".

\section{Future Directions}

As the nature and importance of fundamental value orientations as an influence on administrative decision making perceives increasing attention in the literature, there is an emerging contingent need to clarify aspects of the discussion. In today's mushrooming pluralistic societies, administrators are becoming "increasingly sensitive to values issues" (Begley, 1996, p. 405) where there are no "straightforward solutions" (Ryan, 2000). Right solution requires sophistication about the nature of values (Hodgkinson, 1991, 1996). However, considering the high level of ambiguity that is embedded in understanding the nature and function of values, value finesse may not be easily attained. Therefore, it is necessary to visit and enhance our efforts to clarify and cohere dialogue in the area of values and leadership. The contention is that a better understanding of varying and competing terminology embedded in value inquiry is helpful for understanding the challenge that administrators face as facilitators of value-laden decision making among educational stakeholders. There is also the need to acknowledge the contextual ambiguity enveloping educational leaders engaged in the practice of moral leadership where there is a concomitant recognition of value pluralism. Consequently, a better understanding of the implications that multiple meanings and interpretations related to value theory have for the practice of moral leadership is of fundamental importance. 
Although some might consider these matters to be the exclusive domain of ethical philosophers and academic researchers, others would disagree. Walker's (1994) study of the notions of ethical among educational leaders suggests that it is important to examine practitioner knowledge, understandings and interpretations in this area. This means it is necessary to examine educational settings to better appreciate emergent multiple meanings and realities related to context; time, and language. Questions to be asked are abundant. For example:

- Is it necessary for all participants involved in collaborative decision making which often gives rise to value conflicts - to not only arrive at shared values but to begin with shared conceptualisations of the nature of values?

- How do leaders facilitate shared decision making when stakeholders subscribe to different value orientations and hold different and offen subconscious interpretations of value theory?

- How can leaders facilitate the process of arriving at the "common good"?

- What is the nature of the relationship between language and power in the process of achieving common ground?

- What is the role of imagination in moral leadership endeavours and how can the imagination be cultivated?

- Can reconceptualizations of time enhance creativity and imagination and by extension inform moral leadership? If so, how?

This challenging (but not exhaustive) list of questions and the partially formed answers provided in this paper have very definite implications for future directions in the study of values and educational leadership. In the wake of such queries and coupled with the preceding ruminations - comes the compelling recognition that value-oriented inquiry must continue to stimulate and evoke critical dialogue and debate. Failure to meet the challenge will almost certainly cause us to fall short of even approaching the idea of moral leadership in the encumbered world of the educational practitioner.

\section{References}

- Beck, C. (1993). Learning to live the good life: Values in adulthood. Toronto, Canada: OISE Press.

- Beck, C. (1996). "Values, school renewal and educational leadership". Paper presented at the 1996 Toronto conference on values and educational leadership, Toronto. 
- Begley, P.T (1996). "Cognitive perspectives on values in administration: A quest for coherence and relevance". Educational Administration Quarterly, 32, 3, 403-26.

- Bessetti, L., Brown, D.J., Carlin, D., Goode, H. \& Lafleur, C. (1999). The values of educational odministration. In Begley, P.T. \& Leonard, P.E. (Ed.). London: Falmer Press.

- Duke, D.L. \& Canady, R.L. (1991). School policy. New York: McGraw Hill, Inc.

- Greenfield, T.B. (1979). "Organisation theory as ideology". Curriculum Inquiry, 9, 2, 97-111.

- Hodgkinson, C. (1978). Towards a philosophy of Administration. Oxford: Blackwell.

- Hodgkinson, C. (1991). Educational Leadership: The moral art. Albany, NY: Suny Press.

- Hodgkinson, C. (1996). Administrative philosophy: Values and motivations in administrative life. London: Elsevier Science Ltd.

- Lakomski, G. (1987). "Values and decision making in educational administration". Educational Administration Quarterly, 23, 3, 70-82.

- Rokeach, M. (1973). The nature of human values. New York: The Free Press.

- Rokeach, M. (1979). Understanding the human values. New York: The Free Press.

- Ryan, J. (2000). "Beyond the veil: Moral educational administration and inquiry in a postmodern world". In Begley, P.T. (Ed.). Values and Educational Leadership. Albany, New York: Suny.

- Scott, D.K. \& Hart, W.G. (1979). Organisational America. Boston, MA: Houghton Mifflin.

- Shafritz, J.M. \& OHt, J.S. (1996). Classics of organization theory. New York: Wadsworth Publishing.

- Telford, H. (1996). Transforming schools through collaborative leadership. London: Falmer Press.

- Walker, K.D. (1994). "Notions of ethical among senior educational leaders". The Alberta Journal of Educational Research, 40, 1, 21-34.

- Willower, D.J. (1994). Educational administration: inquiry, values, practice. Revised edn., Lancaster, PA: Technomic Company, Inc. 